\title{
NOTES ON PORTO RICAN SCALE PARASITES
}

\author{
By H. L. DOZIER ${ }^{1}$
}

The following notes are here given as a small contribution to our knowledge of the enemies of certain scale insects in Porto Rico. The writer wishes to express his thanks to Mr. A. B. Gahan of the United States National Museum for his kindness in helping to compare and identify the parasites recorded in this paper.

\section{Leptomastix dactylopii Howard \\ (1885, U. S. Bur. of Ent., Bul. 5, p. 23)}

This species was described briefly by Dr. Howard in 1885, and again in 1892 (Proc. Ent. Soc. Wash., II, p. 237) he states that is a not uncommon parasite of the common mealy-bug in the greenhouse at Washington, D. C., and notes the following:

"Miss Lillie Sullivan has found it the present season infesting mealy-bugs upon house plants, and informs me that she can at once recognize infested scales by the fact that they lose almost entirely their wax or meal-like covering and swell up into yellow objects closely resembling dipterous puparia. She has shown me several from which the parasites have emerged and I have been greatly struck by this resemblance which is heightened by the fact that the parasite in issuing cuts off a cap at the end of the scale insect, just as the dipterous insect forces off the end of its puparium. This is an abnormal habit so far as I know, as allied parasites are accustomed to gnaw holes through their hosts, removing the epidermis in small particles and leaving no cap. The resemblance of the swollen mealy-bug to a dipterous puparium is so strong that only by close search with a strong lens can the observer, by finding the minute legs and antennae, be certain of its identity.",

These early observations of Dr. Howard have been confirmed by the writer.

Upon further study and comparison of material, dactylopii may prove to be identical with the European histrio described by Mayr in 1875 , and this is highly probable as both species seem to be rather variable in color and size.

Female: Head somewhat lenticular, slightly convex; ocelli arranged in triangle, the hind ones farther apart from each other than from the inner margin of the eye; antennae very long, as long or slightly longer than the body, slender and clothed with delicate short hairs; the scape as long as the first two funicle joints together, pedicel twice as long as wide, and about half as long as the following joint, club as long as the last two funicle joints com-

\footnotetext{
1 Formerly Chief Entomologist of the Insular Experiment Station.
} 
bined, slightly broader than the funicle and rounded on end. Thoráx moderately arched, mesonotum somewhat shining, with scattered setae. Scutellum dull, with sparse setae; at its posterior apex are two distinctly larger, more prominent black setae. Vertex and thorax with indistinct scale reticulations under high microscopic power. Abdominal segments difficult to distinguish.

The general color of the female is honey-yellow with distinct reddish tinge on the mesonotum, the antennae and eyes blackish, the

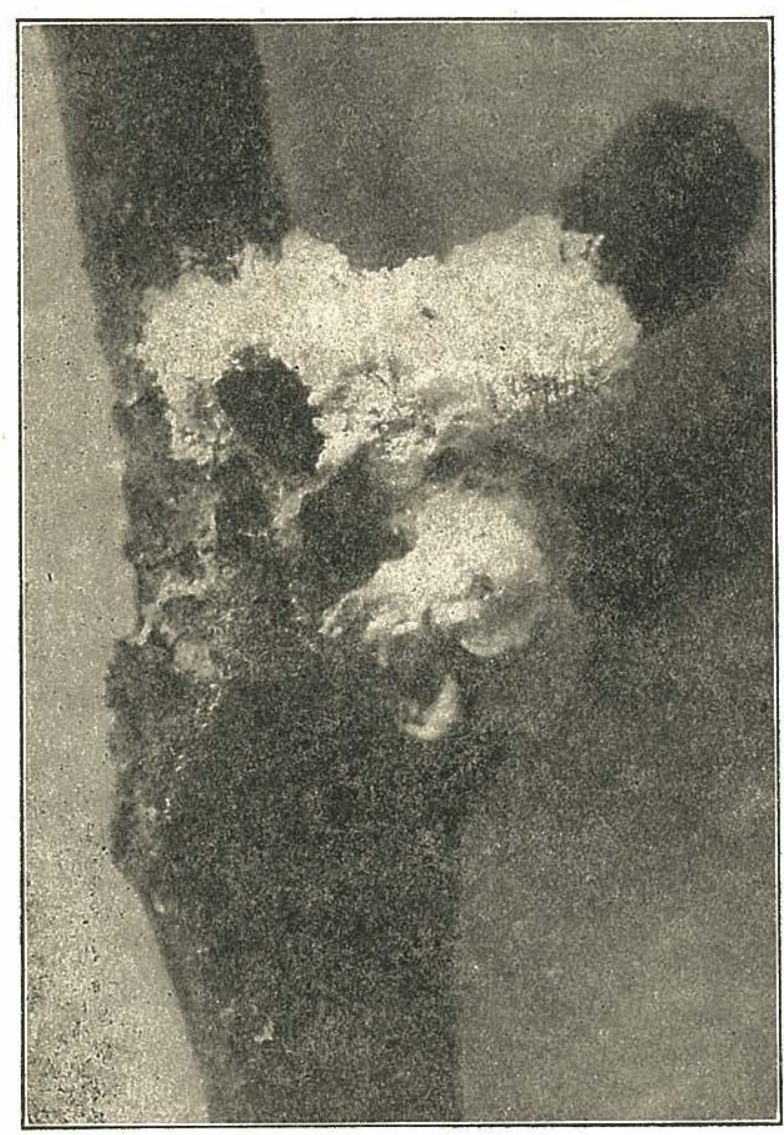

FIG. 1.-Pseudococcus citri parasitized by Leptomastix dactylopii hind margin of th e pronotum, scutellum, dorsum of abdomen, and hind femora more or less dusky.

Male: Similar to $\mathrm{female}$ in structure but distinguished at once by its antennae $\mathrm{which}$ a re distinetly longer than the entire body and the funicle is furnished with numerous 1 o $\mathrm{ng}$ hairs which are not arranged in whorls. $\mathrm{M} \mathrm{u} \mathrm{ch}$ darker than the female, the amount of black on thorax quite variable, the mesonotum, distinctly yellow. Antennae, hind tibiae and tarsi fuscous.

Length of female, $1.50 \mathrm{~mm}$.; male, $0.97 \mathrm{~mm}$.

As the original description is now inaccessible to most workers, the above brief re-description is given. It is drawn up from a female reared by the writer from Pseudococcus citri at Río Piedras, Porto Rico, June 8, 1925, and a series of three females and four males reared by F. Sein at same locality from the same host, November 
1925. There is also at hand a male reared by the writer at New Orleans, La., September 1922.

\section{Achrysopophagus seini, new species}

Resembling a Cheiloneurus very closely and placed in Achrysopophagus only because of its slightly narrower head and the absence of distinct scrobal grooves. Very close to A. dactytopii Howard but differs in having the fore-wings less enfumed and the stigmal vein is very different.

Female: Head slightly wider than long; ocelli arranged in an acutely angled triangle. Antennal scape slightly expanded beneath,
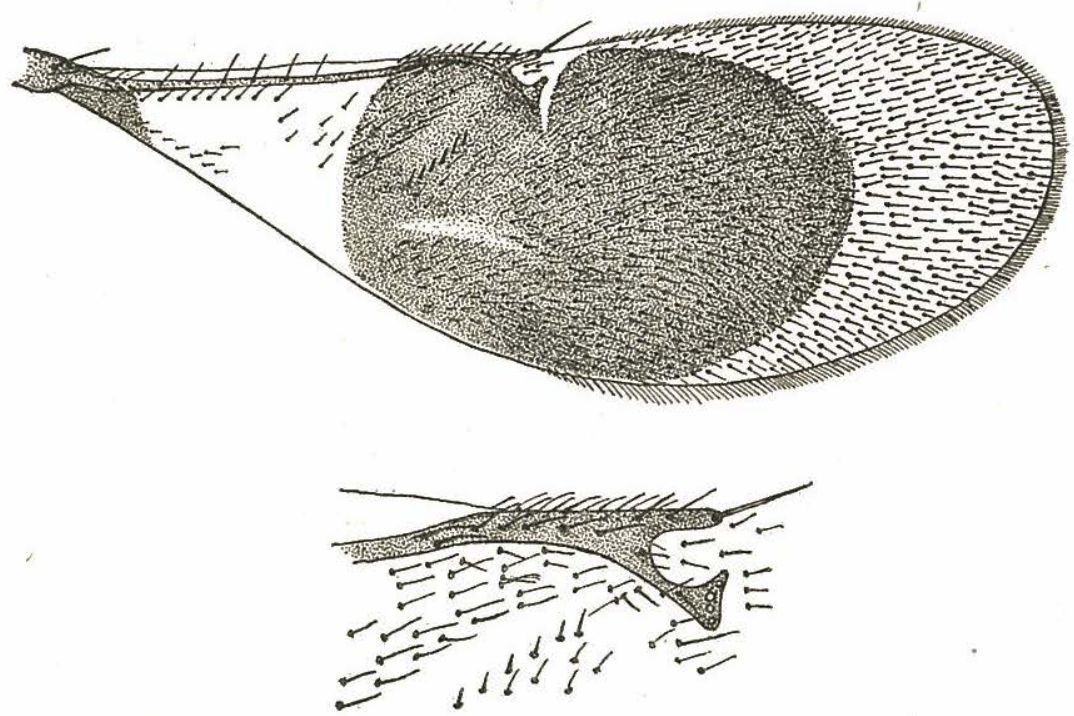

FIG. 2.-Forewing of female Achrysopophagus seini Dozier

nearly four times as long as its widest width; pedicel as long as the first two funicle joints combined; first four funicle joints sub-equal, the fifth and sixth longer and wider; club three-jointed distinctly wider than the scape and of about the same length, obliquely truncate. Mesothoracic scutum over twice as wide as long. Scutellum about as long as wide, with the characteristic tuft of black bristles, distinctly reticulated. Mesoscutum with dark hairs anteriorly and on hind margin but with numerous setigerous punctures in the silvered area. Abdomen shorter than the thorax, the ovipositor sheath distinctly exserted.

General color a yellowish orange, the abdomen usually slightly darker; eyes dark. Antenna testaceous yellow except a fine streak along center of upper margin of scape, the pedicel, first funicle joint 
partly, and the club, which are brownish-black. Legs pale yellowish white, the hind femora and tibiae with slight infuscations. Forewings with characteristic enfumation on disc as in Fig. 2.

Length, exclusive of ovipositor, $1.10-1.4 \mathrm{~mm}$.

Male: Antennae entirely different from those of female, easily differentiating the sexes, uniform light brown in color; funicle joints turnished with partial whorls of long diverging hairs. General color dark-brown, the front and middle legs pale, the wings hyaline without embrowning.

Length, $.78 \mathrm{~mm}$.

Described from a female reared by the writer (U. S. National Museum type No. 40351) from Pseudococcus citri material on croton at Río Piedras, Porto Rico, June 21, 1925, and a series of four females and one male reared by Francisco Sein in November 1925 from the same host and locality. The mealy bugs were parasitized by Leptomastix dactylopii and the parasitized individuals were placed in shell vials by Mr. Sein, and from some of these issued this species. Arfchrysopophagus scini is most probably secondary on the Lepto-

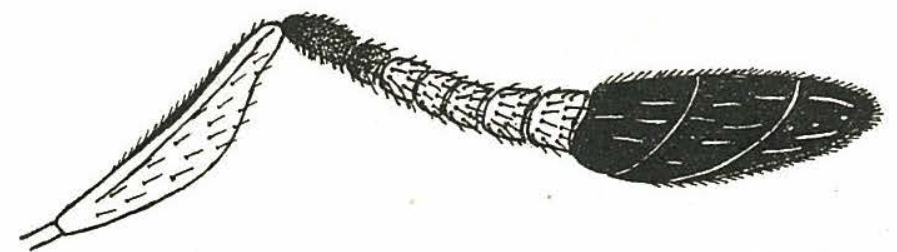

FIG. 3.-Antenna of female Achrysopophagus seini Dozier

mastix, although absolute proof is lacking. All material was mounted in Canada balsam on slides and is not entirely satisfactory.

\section{Achrysopophagus gahani, new species}

This species is very closely allied to A. seini and dactylopii How. and was first placed as the latter. The original description of $A$. dactylopii is too meager to allow for positive identification but through the kindness of Mr. A. B. Gahan of the U. S. National Museum the Porto Rican specimen was carefully compared by him with the type of dactylopii and found to be a distinct and apparently undescribed species, dactylopii having the ovipositor very distinctly exserted, the head decidedly longer than broad when viewed from the front, and the antennal club is much larger than in gahani.

Female: Antennal scape much expanded beneath, pedicel as long as first two funicle joints combined, the fifth and sixth joints distinctly wider and longer than the preceding funicle joints; club three-jointed, distinctly larger and wider than remainder of antenna. 
Scutellum with the characteristic tuft of black bristles at apex, reticulated. Abdomen about as long as thorax, the ovipositor sheath only slightly exserted. The structure of the stigmal vein is very distinctive, readily separating it from seini.

General color yellowish orange. Forewings hyaline and bare on hasal third except slight embrowning at base, remainder distinctly embrowned with only the apical tip hyaline as in Fig. 4. The antennal scape testaceous yellowish, lower edge infuscated along basal half,

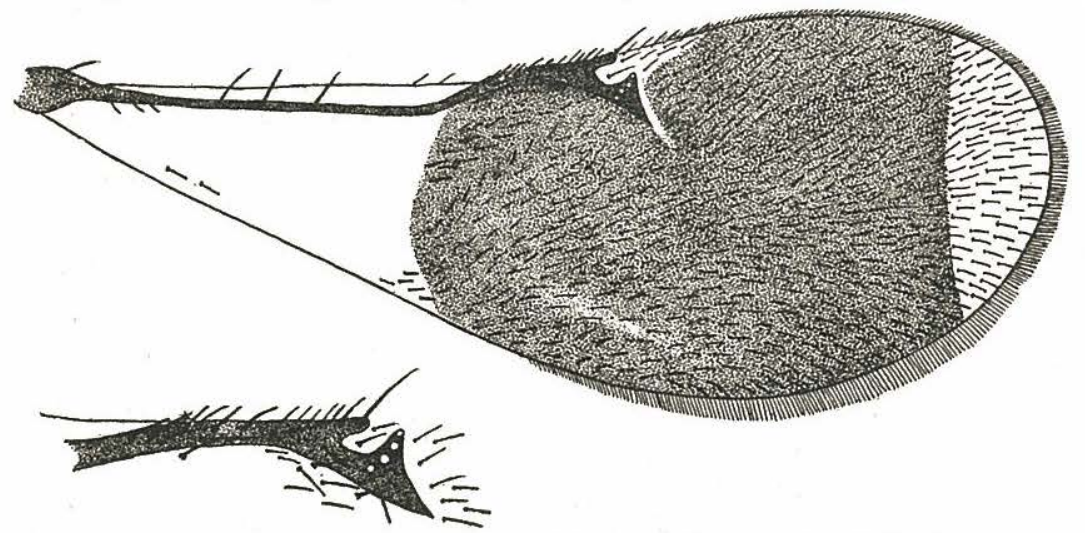

FIG. 4.-Forewing of female Achrysopophagus gahani Dozier

the pedicel and funicle distinctly darker yellowish-brown, the club deep fuscous.

Length, exclusive of ovipositor, $1.25 \mathrm{~mm}$.

Described from a single female reared by the writer from Pseudococcus citri material on croton June 18, 1925, at Río Piedras, Porto Rico (U. S. National Museum type No. 40352). It is most probably a secondary parasite. Dr. Howard in describing his $A$. dastylopii states that a large number were bred from the common mealy-bug in

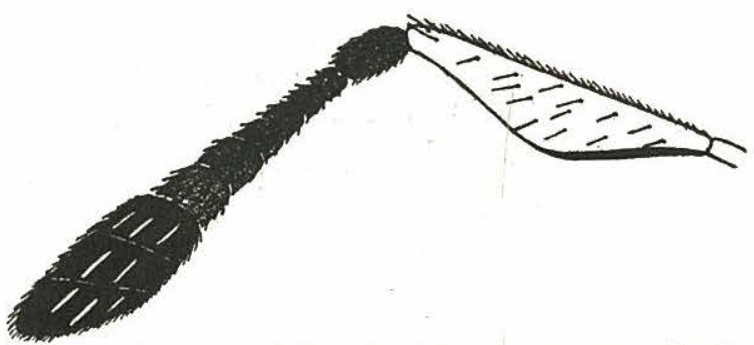

FIG. 5.-Antenna of female Achrysopophagus gahani Dozier company. with Leptomastix dactylopii Howard.

Thysanus nigrus (Ashmead)

(1900 Proc. U. S. N. Mus., xxii, p. 410, Signiphora)

Two females of this species were reared by the writer at Río Pie. 
dras from Pseudococcus citri material on croton June 22, 1925, and a male was reared from similar material July 3, 1925.

\section{Thysanus bifasciatus (Ashmead)}

(1900 Proc. U. S. Nat. Museum, xxii, p. 411, Signiphora)

Four specimens reared in November 1925 by Francisco Sein from parasitized Pseudococcus citri placed in shell vials, have been compared by Mr. Gahan with the unique type of bifasciata and prove so be the same species. It is most probably hyperparasitic on either Leptomastix dactylopii or Achrysopophagus seini, both of which were reared from the same material. T. bifasciatus was described from a single female specimen collected by H. H. Smith on St. Vincent, and it is interesting to have more definite information concerning this distinctly West Indian species.

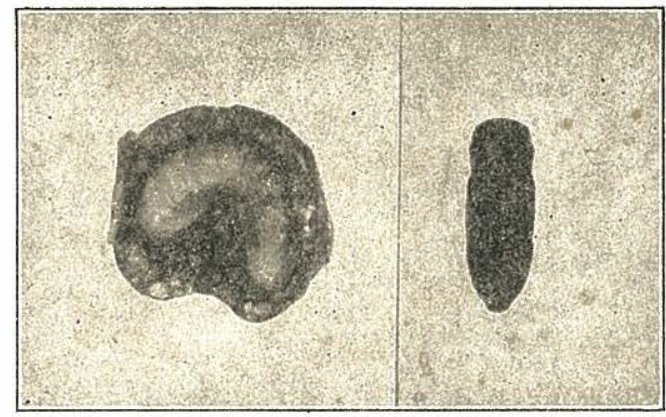

FIG. 6.-Eupelmus saissetiae; (a) full-grown larva in situ; (b) pupa, greatly enlarged
Thysanus flavus

(Girault)

(1913 Proc. U. S. N. Mus., 45, p. 213, Signiphora)

A single female was reared by the writer from lignum-vitae material in f e s t e d with Aleurothrixus howardi at $\mathrm{C}$ entral Aguirre, Porto Rico, July b, 1925.

Lecaniobius cockerelli Ashmead

(1896 Proc. Ent. Soc. Wash., vol. 4, p. 17)

A number of specimens were reared from Saissetia oleae on avocado at Río Piedras, May 26, 1925.

\section{Eupelmus saissetiae Silvestri}

(1915 Bol. Lab. Zool. Agr. Portici, vol. 9, p. 289)

The Black Scale, Saissetia oleae, is held in partial check in Porto Rico by parasites and apparently Eupelmus saissetiae is rather abundant. On June 11, 1925, many mature scales were found to contain grubs in various stages of development, one to a scale, the full-grown grub measuring $3.75 \mathrm{~mm}$. A number were removed from the scale coverings and placed in a vial without food and pupated on June 13th. 
Shortly afterwards the adults issued, showing a great variation in size, due most likely to the cutting short of their food supply.

\section{Pseudoteroptrix imitatrix Fullaway}

(1918 Proc. Haw. Ent. Soc., vol. 3, p. 464)

A single specimen reared by the writer from the mining scale, Howardia biclavis, on Acalypha at Río Piedras, November 24, 1924, has been determined by Mr. Gahan as this species. It is recorded as an abundant parasite of Howardia biclavis in Hawaii but out of a large amount of material placed in parasite cages in Porto Rico only the single specimen was obtained.

Plagiomerus cyanea (Ashm)

(1886 Entomologica Americana, IV, p. 150 , Comys)

This species is easily placed generically by the four-jointed funicle and the cluster of flattened scales at the apex of scutellum. One species of the genus, $P$. diaspidis, was reared in New Mexico from Diaspis casti, and Girault (Ann. Ent. Soc. Amer., Vol. VIII, p. 280) stated that Comys cyanea Ashmead from Florida should be placed in Plagiomerus and is very much like $d i$ as $p i d i s$ but has joints three and four of the funicle white. Mr. P. H. Tim-

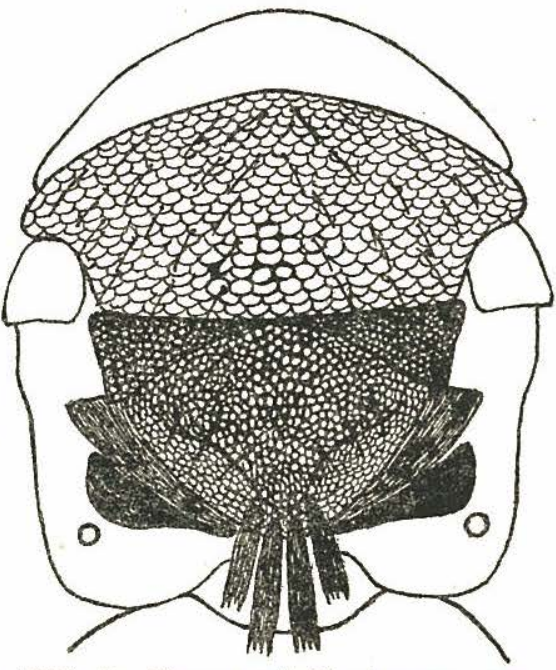

FIG. 7.-Thorax of Plagiomerus cyanea greatly enlarged, showing the flattened scales

berlake, to whom the writer sent his material for study, writes that "it differs from the described species diaspidis Cwfd., cyanea (Ashm.) and hospes (Timb.) in having the scale-like setae extremely broad and also from cyanea in having the mesonotum much less brilliantly blue, and its pubescence dark instead of white." After considerable study and comparison with the type of Comys cyanea, Mr. Gahan and the writer decided that this material is most probably cyanea Ashmead. The type of cyanea from Florida is card-point mounted and the relative width of the scale-like setae is difficult to discern although they appear slightly narrower than in the Porto Rican material. 
Female: Antennae nine-jointed, the pedicel longer than the first two funicle joints together; the funicle four-jointed, its second joint distinctly shorter than the others and only half as long as wide; hairs prominent. In slide-mounted specimens the scutellum is deeply and roundy reticulated, the mesonotum more coarsely and less distinctly so ; from base of scutellar fold apex, arise a cluster of muchflattened, very broad scales and just above the fold on each side is an oblique row of three prominent setae. Mesonotum with rather long black setae. Wings hyaline, strongly iridescent, densely and finely eiliated over apical half, the hairless oblique streak very difficult to distinguish on account of the fineness and sparseness of cilia over the basal area; submarginal vein with seven prominent setae; marginal vein not punctiform, and the post-marginal short but distinct. Ovipositor very deeply seated, but with a short portion extending beyond abdomen.

Head and body blackish with decided metallic bluish-green reflections. Specimens mounted in balsam on slides show dark-brown. Antennae are pale yellowish, most of the pedicel, the first two funicle joints, and most of the first and last joint of the club, fuscous. Legs blackish, with following exceptions: the knees and apices of

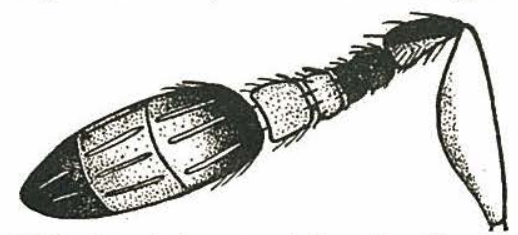

FIG. 8.-Antenna of female Plagiomerus cyanea (Ashm.) the front tibiae, basal half and apices of the middle femora and base and apical half of middle tibiae, the base and apices of the hind tibiae, and all tarsi, pale. The brown portions of the legs show coarse reticulation under high power. Length, . $80-.90 \mathrm{~mm}$.

Re-described from a series of card-point-mounted females and four individually slide-mounted females, all reared by the writer during June and July, 1925, from lignum vitae, infested with Ceroplastes cirripediformis, Aspidiotus cyanophylli, and Aleurothrixus howardi, collected at Central Aguirre, Porto Rico. Without very much question this species is a primary parasite of the wax scale.

\section{The Genus Aspidiotiphagus Howard}

This genus has been recently revised by the Italian Entomologist, Guido Paoli (Bol. della Soz. Ent. Italiana, Vol. 58, July 1926), and he now recognizes as valid two species and one variety, citrinus var. agilior Berl. Ashmead's A. aleyrodis as represented in the U. S. National Museum by three pin-mounted specimens is not an Aspidiotiphagus but is probably an Encarsia. Heretofore A. lounsburyi has been known only from the Island of Madera, and Liguria, Italy, where at the latter place it was introduced and established as a parasite of Chrysomphalus dictyospermi. It is therefore of interest to 
record the presence of this species in the New World. Specimens of both typical citrinus and lounsburyi were submitted to Dr. Paoli who checked on the identification.

\section{Key to Species of Aspidiotiphagus}

First joint of club distinctly shorter than either of the apical two, submarginal vein always with a single seta, marginal setae $3-4$ lounsburgi Berl. and Paoli. First joint of club nearly as long as each of the apical two, submarginal vein with two setae, marginal setae 4-6 _citrinus (Craw.)

Aspidiotiphagus citrinus (Craw.)

(1891 Destructive Insects, Sacramento, Cal.; Coccophagus)

The writer has examined in the U. S. National Museum slides containing specimens reared from Aspidiotus aurantii at San Francisco, Cal., April 1902, by Alex Craw. Without the original types, which are apparently lost, $\mathrm{th}$ is material must be considered as typical and as authoritative as any. These specimens show nearly the e $\mathrm{n}$ tire adomen

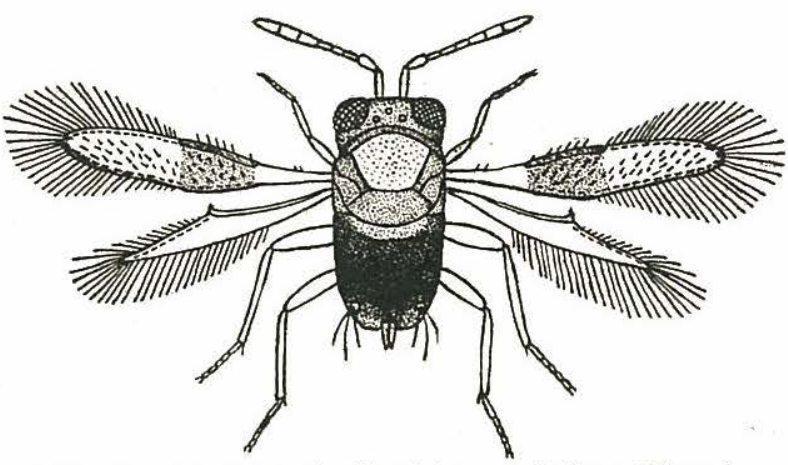

FIG. 9.-Adult of Aspidiotiphagus citrinus (Craw.) darkened and not distinctly banded as in the familiar drawing that has served to illustrate this species for so many years. They show the first joint of the club almost as long as either of the apical two, the submarginal vein always with two setae and the number of setae on edge of the marginal vein varying from four to five, the latter number being the rule.

Female: Head as wide as thorax; antennae eight-jointed, the scape long and fusiform; club elongate, the last two joints subequal and only slightly longer than the first, and miscroscopic elevations present as in figure; eyes large and prominent. Scutellum with two rather distinct pores. Forewings are rather wide and the anterior margin well-rounded; the marginal vein is furnished with four to five marginal setae, that number being variable, often a specimen having four marginal setae on one wing and five on the 
other; the submarginal vein, however, always has two fine setae; the disc of the forewing with numerous cilia arranged in three or four more or less distinguishable rows and there is a bare area about the stigma.

Head and body brown with the exception of the vertex, lower two-thirds of mesonotum and the parapsides, all of which are yellowish. Antennae uniform smoky. Anterior wings with the marginal vein dusky, and with dark infumation or clouding beneath its length, extending across the entire width of wing. Legs pale yellowish.

Length of body, .36-.44 mm.; expanse, .920-1 bb.; greatest width of forewings, .08-.10 mm.;

Male unknown.

The above description is drawn up from numerous slide-mounted and fresh specimens reared from Asterolecanium pustulans on va-

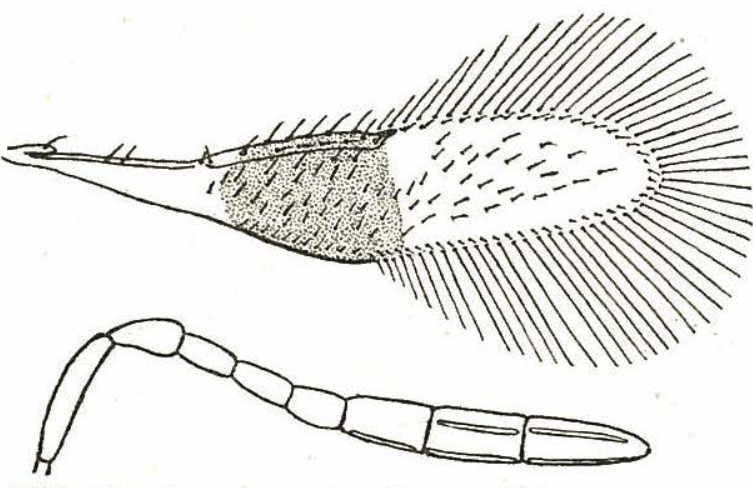

FIG. 10.-Forewing and antenna of Aspidiotiphagus sitrinus (Craw.) rious hosts during 1925 at Río Piedras, Porto Rico; from Diaspis carueli on juniper, $\mathrm{N}$ e w a r k, Delaware, October 16, 1925; and from Chrysomphalus tenebricosus on willow at New Orleans, La., February 11, 1926.

\section{Aspidiotiphagus lounsburyi}

(1916 Redia, XI, fasicle 1, p. 305, Prospaltella)

Readily distinguished from Aspidiotiphagus citrinus by its more yellowish color, the first joint of the club being only about half the length of the second joint, and especially by having only a single seta on submarginal vein.

Female: Head as wide as thorax, the eyes large and prominent. Antennae eigth-jointed, long and slender, especially the fusiform scape; pedicel distinctly larger and wider than the funicle joints which are all subequal in length; first joint of club only about half as long as the second and of equal width. Ocelli placed in equilateral triangle. Forewings long and narrow, narrower and more pointed at tip than those of $A$. citrinus; marginal cilia very long, those on hind margin distinctly longer than those on anterior margin; the 
marginal vein furnished with three marginal setae, although some have four and there is a single submarginal vein seta.

The entire head and body is of a dirty yellow color, the posterior two-thirds of the mesonotum and the parapsides being the lightest in coloration. Some specimens are much darker, approaching more the coloration of citrinus. Eyes dark reddish brown. Ocelli distinctly carmine red. Antennae dirty yellowish. Forewings with infuscation across the width of the wing beneath the marginal vein similar to citrinus. The cilia on dise are fewer than in citrinus and arranged in two or three rows. Legs pale.

Male unknown.

Length, .30-.36 mm.; expanse, $.68-.80 \mathrm{~mm}$.; greatest width of forewing, $.06 \mathrm{~mm}$.

Above description made from a slide containing seven females and a slide containing four females reared by the writer from Aspidiotus destructor on plant at Río Piedras, Porto Rico, May 29,

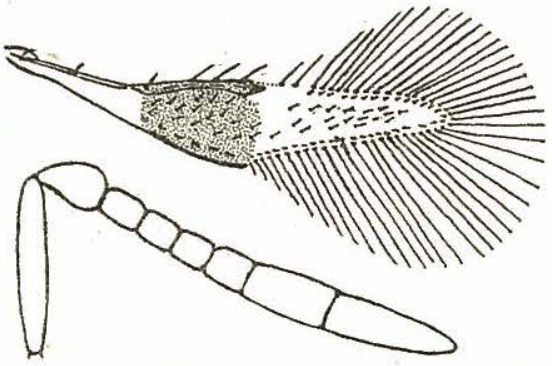

FIG 11.-Forewing and antenna of Aspidiotiphagus lounsburyi Berl. and Paoli 1925; and four females on slide reared from scale material on citrus, Río Piedras, Porto Rico, May 21, 1925; six females on slide reared from Diaspis pentagona on mulberry June 5, 1925, at Río Piedras, Porto Rico. The writer has for comparison many specimens from the Island of Madera, reared from Chrysomphalus dictyospermi by Guido Paoli, June 1923. 